\begin{tabular}{|l|l|}
\hline JURNAL ABDI MASYA & \begin{tabular}{l} 
Volume 1 Nomor 3 \\
November 2021 \\
pp 125-131 \\
Website: $\underline{\text { https://jurnal.sttw.ac.id/index.php/abma/about }}$ \\
\hline E-ISSN : 2774-2849 \\
p-ISSN : 2774-2881
\end{tabular} \\
\hline
\end{tabular}

\title{
RANCANGAN PENGABDIAN DALAM PEMBUATAN TEMPAT TIDUR TINGKAT TERINTEGRASI MEJA BELAJAR DI PONDOK PESANTREN
}

\section{COMMUNITY SERVICE DESIGN IN MANUFACTURNG OF INTEGRATED BUNK BED- DESK IN ISLAMIC BOARDING SCHOOL}

\author{
Eko Surojo ${ }^{1}$, Teguh Triyono ${ }^{2}$, Nurul Muhayat ${ }^{3}$, Moch Chamim ${ }^{4}$, Bambang \\ Margono $^{5}$, Triyono $^{6 *}$ \\ 1,2,3,6 Prodi Teknik Mesin, Fakultas Teknik, Universitas Sebelas Maret Surakarta \\ ${ }^{4,5}$ Prodi Teknik Mesin, Sekolah Tinggi Teknologi Warga, Surakarta \\ *Emai: triyono74@staff.uns.ac.id
}

\begin{abstract}
ABSTRAK
Pondok Pesantren adalah salah satu jenis tempat pendidikan formal maupun non formal yang selain memberi materi pelajaran agama juga mengajarkan adab hidup sehari-hari sehingga siswa/santri harus menginap di asrama selama proses pendidikan. Untuk itu, selain sarana prasarana pendidikan, pondok pesantren juga harus menyediakan sarana prasarana kehidupan sehari-hari seperti kamar dan tempat tidur, dapur, sarana olah raga dan lain sebagainya. Karena keterbatasan lahan dan bangunan, satu ruang asrama biasanya dihuni oleh 30-40 santri dengan menggunakan tempat tidur bertingkat. Karena ruang kamar asrama yang kurang memadai, santri biasanya belajar, membaca, mengerjakan Tugas Sekolah di atas tempat tidur. Untuk memberi kenyamanan dalam belajar santri, maka meja belajar yang dirancang terintegrasi dengan tempat tidur untuk menghemat ruang sangat penting untuk dilakukan. Rancangan tempat tidur tingkat terintegrasi dengan meja belajar berbahan dasar baja siku yang bisa dibongkar pasang dengan mudah karena system sambungannya dengan mur-baut. Alas tidur bagian bawah bisa dipisah setengah, lalu dilipat ke arah tiang tempat tidur dan meja belajar bisa didapatkan dengan membuka lipatan berikutnya. Desain ini digunakan untuk program pengabdian yang melibatkan kerjasama bengkel las Sumber Rejeki desa Sawahan, Jaten dan Pondok Pesantren Wirausaha Masjid Fatimah Ar Royyan desa Jongkang, Buran, Karanganyar.
\end{abstract}

Kata Kunci: desain; tempat tidur tingkat terintegrasi meja belajar; bengkel las, baja.

\section{Submit : 7 Juli 2021 Accepted: 4 November 2021 Published: 26 November 2021}

\section{PENDAHULUAN}

Masjid Fatimah Ar-Royyan berdiri tahun 2015 dengan ukuran masjid yang relative kecil yaitu $8 \mathrm{x}$ 8 meter. Masjid ini beralamat di Dusun Jongkang Rt 05/05, Buran, Tasikmadu, Karanganyar. Masjid ini cukup unik karena mempunyai pondok pesantren wirausaha bidang desain grafis dengan jumlah santri saat ini 6 orang dan berencana mengembangkan hingga 20 santri. Pondok pesantren ini gratis dan biaya operasional pondok pesantren ditanggung oleh donatur dari jamaah masjid.

Pondok pesantren ini disebut pondok pesantren wirausaha karena kurikulum pondok pesantren ini dirancang selain memberi materi keagamaan juga mengajarkan materi keterampilan. Saat ini materi keterampilan yang sudah berjalan adalah desain grafis dan sablon kaos dan direncanakan pada tahap selanjutnya membuka materi keterampilan dalam bidang pengelasan logam. Kurikulum pondok pesantren wirausaha Masjid Fatimah Ar Royyan ini dirancang selesai dalam 1 (satu) tahun dengan materi pembelajarannya adalah tahfidz dan tahsin Al Qur'an, kajian kitab pilihan, praktek berdakwah (kultum, khatib, pengelolaan TPA dan sebagainya) dan desain grafis (membuat flyer, poster logo, desain kaos, sablon kaos dan sebagainya). Santri yang lulus dari pondok pesantren ini selain hafal Al-Qur'an juga mempunyai keterampilan yang bisa digunakan untuk meningkatkan penghasilan lulusan. Pondok pesantren ini mempunyai motto "Qur'an inside, skill outside". Gambar 1 mengilustrasikan lingkungan Masjid Fatimah Ar-Royyan dan asrama untuk tempat pelaksanaan proses belajar mengajar pondok pesantren wirausaha. Gambar 2 adalah asrama dan laboratorium komputer untuk menginap dan pelaksanaan pelatihan desain grafis. 


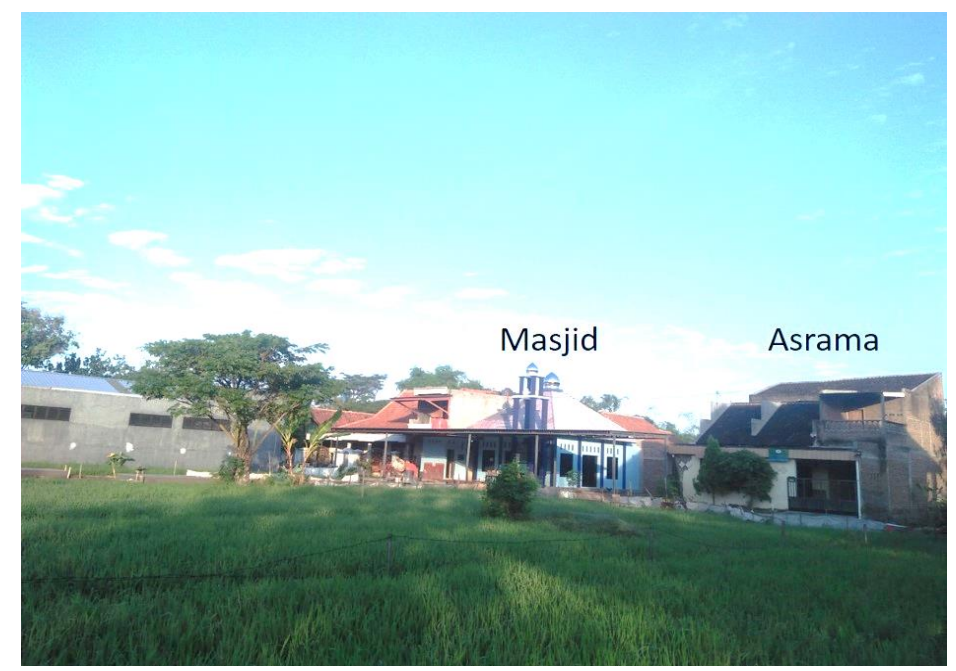

Gambar 1. Kondisi lingkungan masjid dan asrama pondok pesantren wirausaha

Sebagaimana pondok pesantren yang lainnya, santri disediakan asrama dan tempat tidur. Umumnya, dalam 1 ruang asrama sebesar ruang kelas dihuni oleh 30 santri dengan tempat tidur bertingkat seperti terlihat pada Gambar 3, namun untuk pondok pesantren wirausaha Masjid Fatimah Ar Royyan ini, asramanya berupa rumah yang berkamar-kamar dan 1 kamar dihuni oleh 2 santri yang disediakan 2 kasur dan 2 almari pakaian seperti Gambar 2 (a). Kondisi kamar yang seperti ini (Gambar 2(a) dan Gambar 3) memaksa santri jika belajar harus berada di atas tempat tidur dengan posisi sambil tidur. Tentu saja hal ini tidak baik untuk kesehatan santri baik dari segi kesehatan tulang maupun kesehatan mata. Selain itu posisi belajar seperti itu membuat santri cepat lelah dan ketiduran sehingga hasil belajar tidak maksimal.
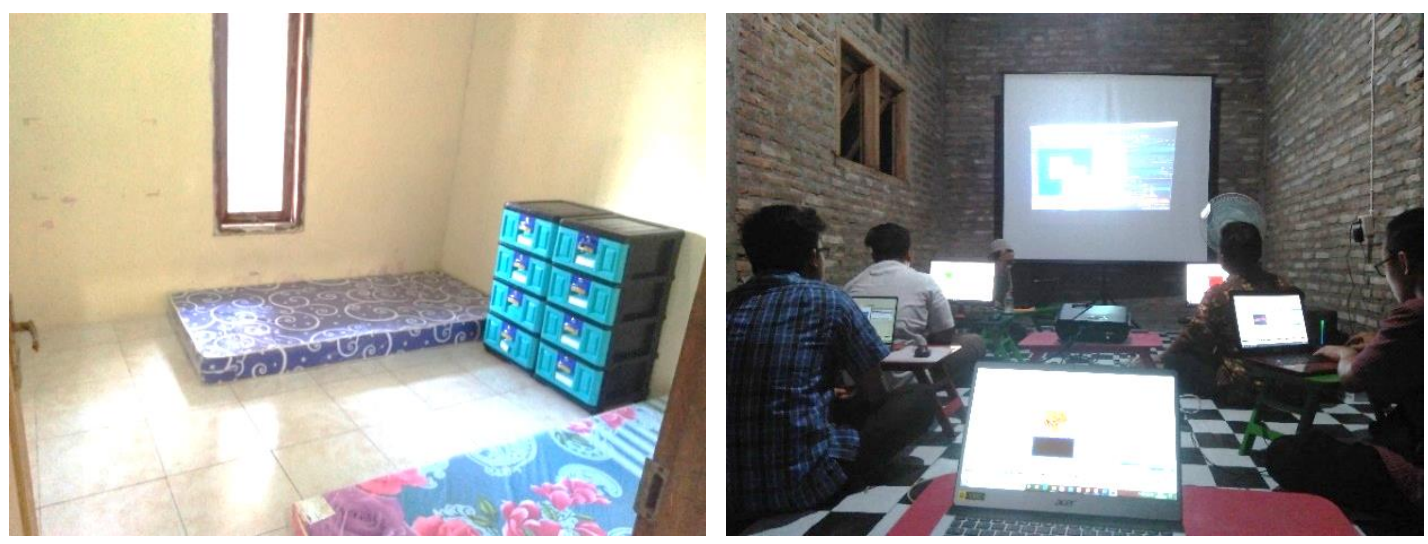

Gambar 2. (a) asrama (b) laboratorium komputer

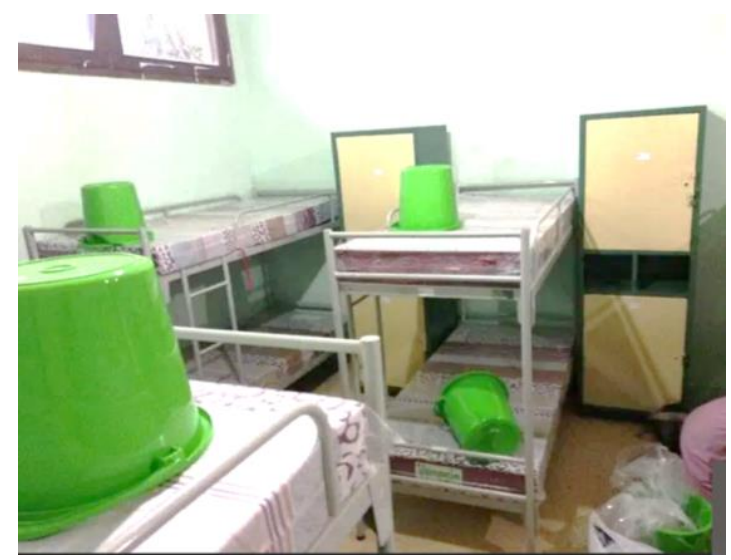

Gambar 3. Kondisi asrama podok pesantren pada umumnya 
Berdasarkan analisis situasi di atas, identifikasi permasalahan berawal dari diskusi tim pengabdi UNS dengan mitra yang tidak produktif secara ekonomi yaitu ketua takmir masjid Fatimah Ar Royyan yang menyelenggarakan Pondok Pesantren Wirausaha. Dari diskusi awal ini, tim peneliti mengetahui bahwa fasiltas belajar yaitu meja belajar santri yang kurang memadai sehingga santri sering ditemukan dalam kondisi tidur sambil berbantal kitab atau buku pelajaran. Setelah ditelusuri, penyebabnya adalah karena santri belajar sambil tiduran di kasur karena tidak tersedia meja belajar. Pengelola pondok sebenarnya bisa saja membelikan meja belajar untuk santri-santri nya akan tetapi karena ruangan asrama yang kurang memadai, maka keberadaan meja belajar akan menambah semakin sempitnya ruang bebas di asrama pondok pesantren. Dari penelusuran ke beberapa pondok pesantren, permasalahan seperti ini merupakan permasalahan umum yang ada di hampir semua pondok pesantren tidak hanya di pondok pesantren wirausaha Masjid Fatimah Ar Royyan. Sehingga usaha-usaha untuk pengadaan tempat tidur yang teritegrasi dengan meja belajar sangat penting untuk dilakukan untuk memecahkan permasalahan di pondok pesantren.

\section{METODE}

Musabbikhah [1], melaksanaan pengabdian berbentuk pelatihan pembuatan pakan ternak, pelatihan usaha berupa kiat sukses wirausaha, cara pemasaran yang tepat sehingga menaikkan semangat usaha, memperluas area penjualan hasil pertanian dan peternakan sehingga dengan strategi pemasaran yang tepat dapat meraih market share yang luas.

Margono [2], merancang mesin tepat guna berupa mesin pencacah rumput gajah dengan kapasitas $500 \mathrm{~kg} / \mathrm{jam}$ berpenggerak motor bensin $5.5 \mathrm{HP}$. Proses pembuatan alat meliputi perancangan, penyiapan bahan, pemotongan dan pengelasan rangka, pemasangaan komponen dan transmisi dan pengujian mesin.

Pengabdian masyarakat yang ditawarkan tim pengabdi UNS berupa desain tempat tidur yang terintegrasi dengan meja belajar sehingga bisa menghemat ruang. Permasalahan berikutnya adalah tempat tidur seperti ini tidak tersedia di pasaran sehingga harus diproduksi sendiri. Dalam memproduksi tempat tidur yang terintegrasi dengan meja belajar ini, juru las harus mempunyai pengalaman mengerjakan struktur yang presisi sehingga mekanisme gerak di tempat tidur tersebut bisa berjalan dengan baik, tidak sesak dan juga tidak longgar. Dengan pertimbangan ini maka, tim pengabdi UNS memutuskan untuk berdiskusi dengan Bengkel Las Sumber Rejeki yang tahun 2019 menjadi mitra PKM UNS dalam sertifikasi pengelasan ISO 9606. Berdasarkan diskusi tersebut, permasalan mitra produktif yaitu Bengkel Las Sumber Rejeki adalah seperti kebanyakan bengkel las lainnya, bengkel las Sumber Rejeki didirikan dengan modal sendiri dan pemilik modal sekaligus sebagai pekerjanya karena pemiliknya bisa mengelas logam. Kemampuan mengelas pemilik bengkel las ini didapat dari belajar secara otodikdak dengan mencoba-coba dan kemampuannya semakin meningkat dengan pengalaman dan sertifikasi maka ada masalah di bengkel las mitra PKM ini yaitu antara lain:

a. Bengkel las Sumber Rejeki belum pernah mengerjakan struktur las dengan mekanisme gerak seperti dalam rancangan tempat tidur yang terintegrasi dengan meja belajar.

b. Juru las belum memahami gambar kerja konstruksi las yang mengandung simbol-simbol pekerjaan las, sehingga jika mendapat pekerjaan yang berdasarkan gambar teknik, juru las belum bisa membaca gambar tersebut. Produk-produk yang dibuat pun tidak dirancang (perhitungan bentuk, kekuatan dan ekonomi) dengan baik, tetapi proses produksinya dikerjakan berdasarkan feeling dan trial and error saat pengerjaan.

c. Juru las tidak memahami perilaku material selama pengelasan, sehingga sering melakukan langkah produksi yang sebenarnya langkah tersebut dapat menurunkan sifat mekanik sambungan las, misalnya setelah mengelas, sambungan las langsung disemprot air agar cepat mendingin

\section{HASIL DAN PEMBAHASAN}

Berdasarkan permasalahan mitra PKM yaitu bengkel las Sumber Rejeki Dusun Sawahan, Jaten, Karanganyar dan Pondok Pesantren Wirausaha Masjid Fatimah Ar Royyan Dusun Jongkang, Buran, Tasikmadu, Karanganyar di atas, maka solusi komprehensif yang ditawarkan oleh tim PKM UNS adalah sebagai berikut: 
a. Solusi untuk Pondok Pesantren Wirausaha Masjid Fatimah Ar Royyan

Dengan mempertimbangkan ruangan yang tersedia dan rencana penambahan santri untuk periode belajar tahun 2021 ini, maka tim pengabdi UNS mengusulkan rancangan tempat tidur yang terintegrasi dengan meja belajar. Tempat tidur ini bertingkat sehingga bisa ditempati oleh 2 santri, dan ketika waktu belajar ranjang bagian bawah bisa dilipat membentuk meja belajar yang sudah dilengkapi dengan lampu belajar. Tempat tidur tingkat dan terintegrasi dengan meja belajar ini terbuat dari baja hollow $4 \times 6 \mathrm{~cm}$ untuk struktur utamanya dan baja hollow $4 \times 4$ untuk struktur asesorisnya, sedangkan meja belajar berbahan dasar kayu. Rancangan tempat tidur tingkat saat digunakan untuk tidur adalah seperti Gambar 4(a), sedangkan rancangan tempat tidur saat digunakan untuk belajar adalah seperti Gambar 4(b).

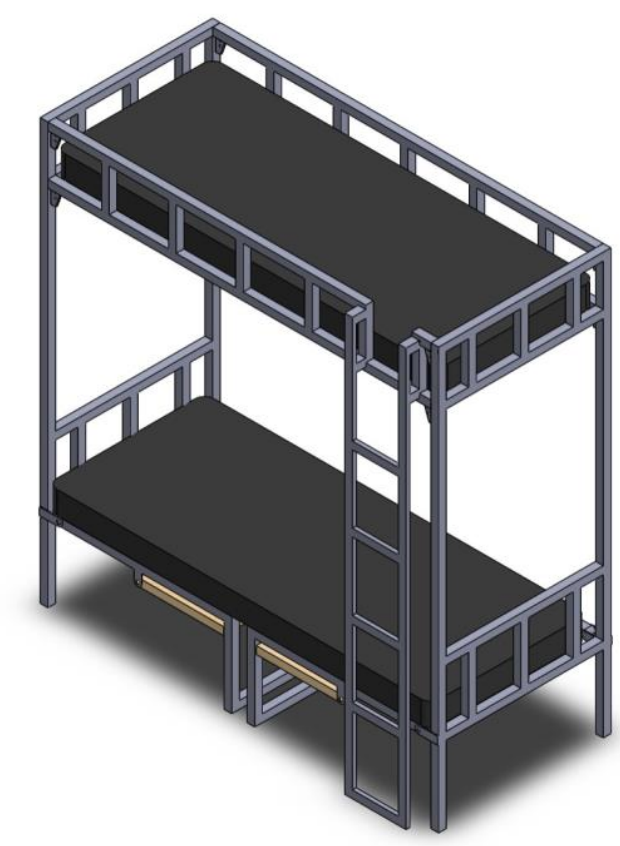

(a) kondisi untuk tidur

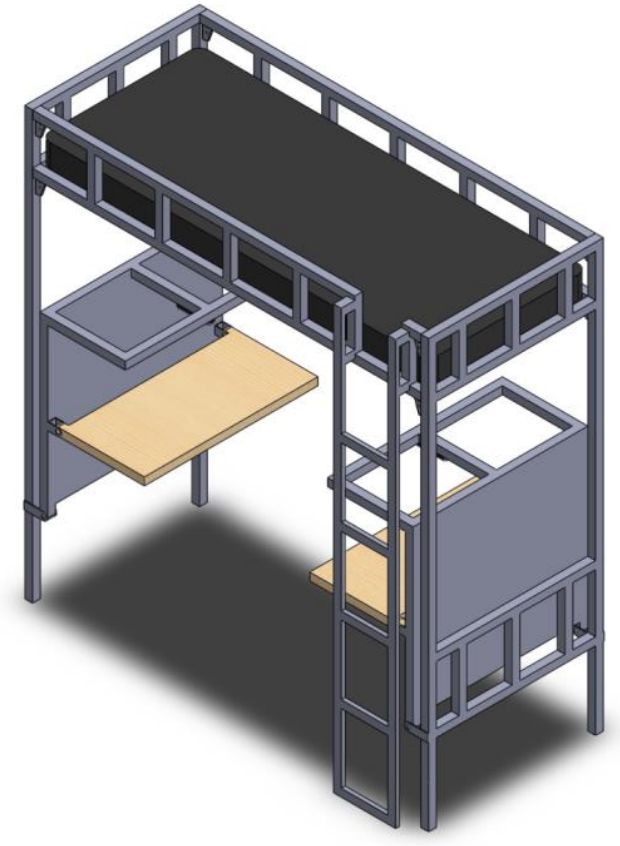

(b) kondisi untuk belajar

Gambar 4. Rancangan tempat tidur-meja belajar terintegrasi

b. Solusi untuk Bengkel Las Sumber Rejeki

Dengan mempertimbangkan kurangnya pengalaman dalam membuat struktur dinamis dan dalam membaca gambar teknik maka tim pengabdi UNS akan memberi pelatihan tentang perancangan struktur tempat tidur tingkat terintegrasi dengan meja belajar lengkap dengan gambar kerja, perhitungan dimensi, perhitungan faktor keselamatan, teknik pengelasan, perilaku material selama pengelasan dan metode pemasarannya. Desain struktur pengelasan secara teknik dinyatakan dalam gambar teknik dengan standard ISO yang memuat simbol-simbol pengerjaan proses pengelasan [3]. Simbol-simbol tersebut mengandung syarat-syarat persiapan, pelaksanaan dan pasca proses pengelasan serta dimensi/ukuran sambungan las. Selain itu, material yang dilas akan mengalami siklus termal mulai dari pemanasan, mencair dan membeku [4]. Kecepatan pendinginan selama pengelasan akan sangat mempengaruhi kekuatan sambungan las dan sifat mekanik lainnya [5]. Karena pemahaman yang kurang terhadap perilaku material selama pengelasan, banyak juru las yang melakukan tindakan yang secara teknik adalah menurunkan sifat mekanik sambungan las, misalkan dengan menyemburkan air setelah pengelasan.

Target pelaksanaan pengabdian pada masyarakat ini adalah untuk meningkatkan tingkat ketercapaian tujuan belajar di pondok pesantren Wirausaha dengan perbaikan fasilitas sekaligus meningkatkan daya saing dan diversifikasi produk Bengkel Las Sumber Rejeki. Pelaksanaan pengabdian melibatkan 3 (tiga) komponen yaitu tim pengabdi UNS, takmir Masjid Fatimah Ar Royyan, dan pemilik dan karyawan bengkel las Sumber Rejeki. Hubungan tim pengabdi UNS dan kedua mitra tersebut diilustrasikan oleh Gambar 5 sedangkan tugas dan peranan masing-masing komponen dalam pengabdian ini adalah seperti Tabel 1. 
Tabel 1. Tahapan pelaksanaan pengabdian pada masyarakat dan solusi permasalahan

\begin{tabular}{|l|l|}
\hline \multicolumn{1}{|c|}{ Tahap } & \multicolumn{1}{|c|}{ Permasalahan yang diselesaikan } \\
\hline $\begin{array}{l}\text { Desain dan pelatihan } \\
\text { desain tempat tidur-meja } \\
\text { belajar terintegrasi }\end{array}$ & $\begin{array}{l}\text { Masalah Bengkel Las Sumber Rejeki: kurang pengalaman } \\
\text { dalam merancang struktur dinamis dan dalam membaca } \\
\text { gambar Teknik. } \\
\text { Solusi: tim pengabdi UNS memberi pelatihan kepada } \\
\text { pemilik dan karyawan Bengkel Las Sumber Rejeki tentang } \\
\text { perancangan struktur tempat tidur tingkat terintegrasi dengan } \\
\text { meja belajar lengkap dengan gambar kerja, perhitungan } \\
\text { dimensi dan perhitungan faktor keselamatan. }\end{array}$ \\
\hline $\begin{array}{l}\text { Proses produksi tempat } \\
\text { tidur-meja belajar } \\
\text { terintegrasi }\end{array}$ & $\begin{array}{l}\text { Masalah Bengkel Las Sumber Rejeki: kurang pengalaman } \\
\text { dalam memproduksi struktur dinamis. } \\
\text { Solusi: karyawan Bengkel Las Sumber Rejeki melakukan } \\
\text { rangkaian proses produksi tempat tidur-meja belajar } \\
\text { terintegraasi sedangkan tim pengabdi UNS mendampingi } \\
\text { pemotongan material dan proses pengelasan. }\end{array}$ \\
\hline $\begin{array}{l}\text { Serah terima tempat tidur- } \\
\text { meja belajar terintegrasi }\end{array}$ & $\begin{array}{l}\text { Masalah Ponpes Wirausaha: luasan ruang dan meja belajar } \\
\text { kurang. } \\
\text { Solusi: tim pengabdi UNS menyerahkan tempat tidur-meja } \\
\text { belajar terintegrasi hasil rancangan tim pengabdi dan hasil } \\
\text { produksi bengkel las Sumber Rejeki. }\end{array}$ \\
\hline $\begin{array}{l}\text { Pasalah Ponpes Wirausaha: Ponpes baru belum dikenal } \\
\text { masyarakat. } \\
\text { Masalah Bengkel Las Sumber Rejeki: sistem pemasaran } \\
\text { tempat tidur-meja belajar } \\
\text { terintegrasi }\end{array}$ & $\begin{array}{l}\text { tradisional sehingga produknya belum dikenal di } \\
\text { masyarakat. } \\
\text { Solusi: tim pengabdi UNS mempromosikan produk tempat } \\
\text { tidur-meja belajar terintegrasi lewat grup WA, FB, Telegram, } \\
\text { Website Prodi tentang kegiatan ini sehingga produk tersebut } \\
\text { dikenal oleh stake holder sekaligus mempromosikan Ponpes } \\
\text { Wirausaha. Promosi dalam bentuk foto dan video }\end{array}$ \\
\hline
\end{tabular}

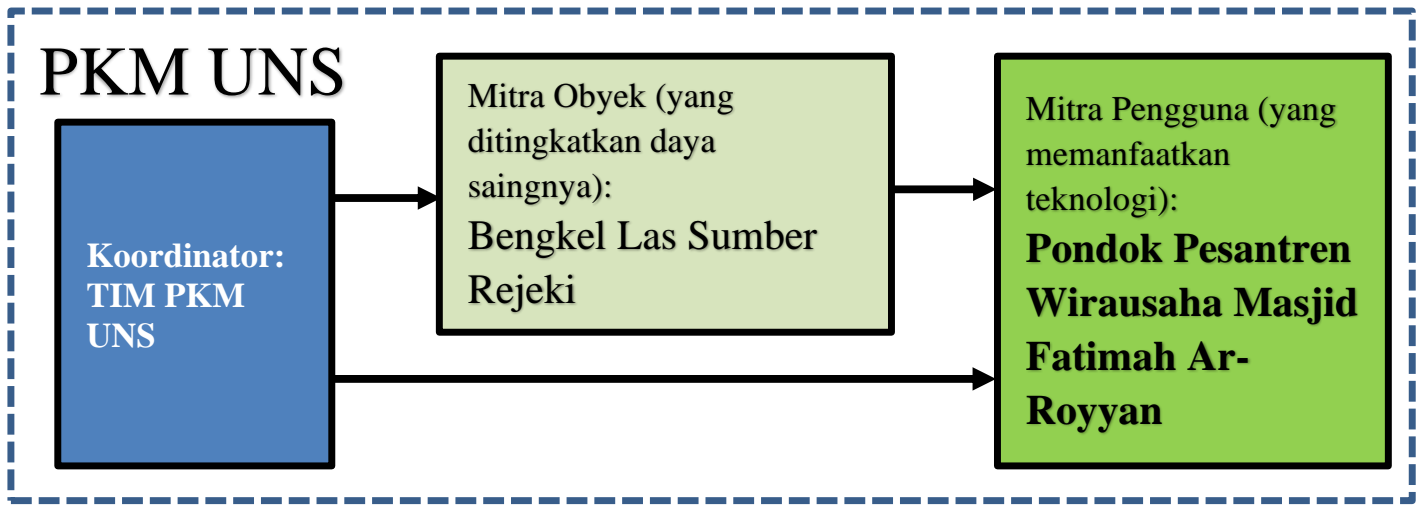

Gambar 5. Hubungan tim PKM UNS dan mitra PKM

Iptek yang ditawarkan dalam pengabdian ini adalah berupa tempat tidur tingkat-meja belajar terintegrasi yang terbuat dari baja hollow yang dirancang sedemikian rupa sehingga produk tersebut bisa berfungsi sebagai tempat tidur sekaligus sebagai meja belajar untuk 2 orang. Produk ini terdapat mekanisme gerak sehingga membutuhkan bantalan (bearing) pada engsel-engsel gerak agar mekanisme gerak bisa berjalan dengan lancar. Baja hollow dipilih sebagai material dalam produk ini karena tersedia dalam berbagai ukuran dan bentuk sehingga rancangan bisa ringan tetapi kuat. Produk tempat tidur tingkat-meja belajar terintegrasi ini bisa dilepas dan dipasang dengan mudah. Gambar teknik produk tempat tidur tingkat-meja belajar terintegrasi adalah terlihat pada Gambar 6 dan 7. Gambar 6 
memperlihatkan gambar teknik tempat tidur tingkat-meja belajar terintegrasi dalam keadaan dipakai untuk tidur, sedangkan Gambar 7 adalah gambar teknik tempat tidur tingkat-meja belajar terintegrasi dalam keaadaan dipakai untuk belajar.

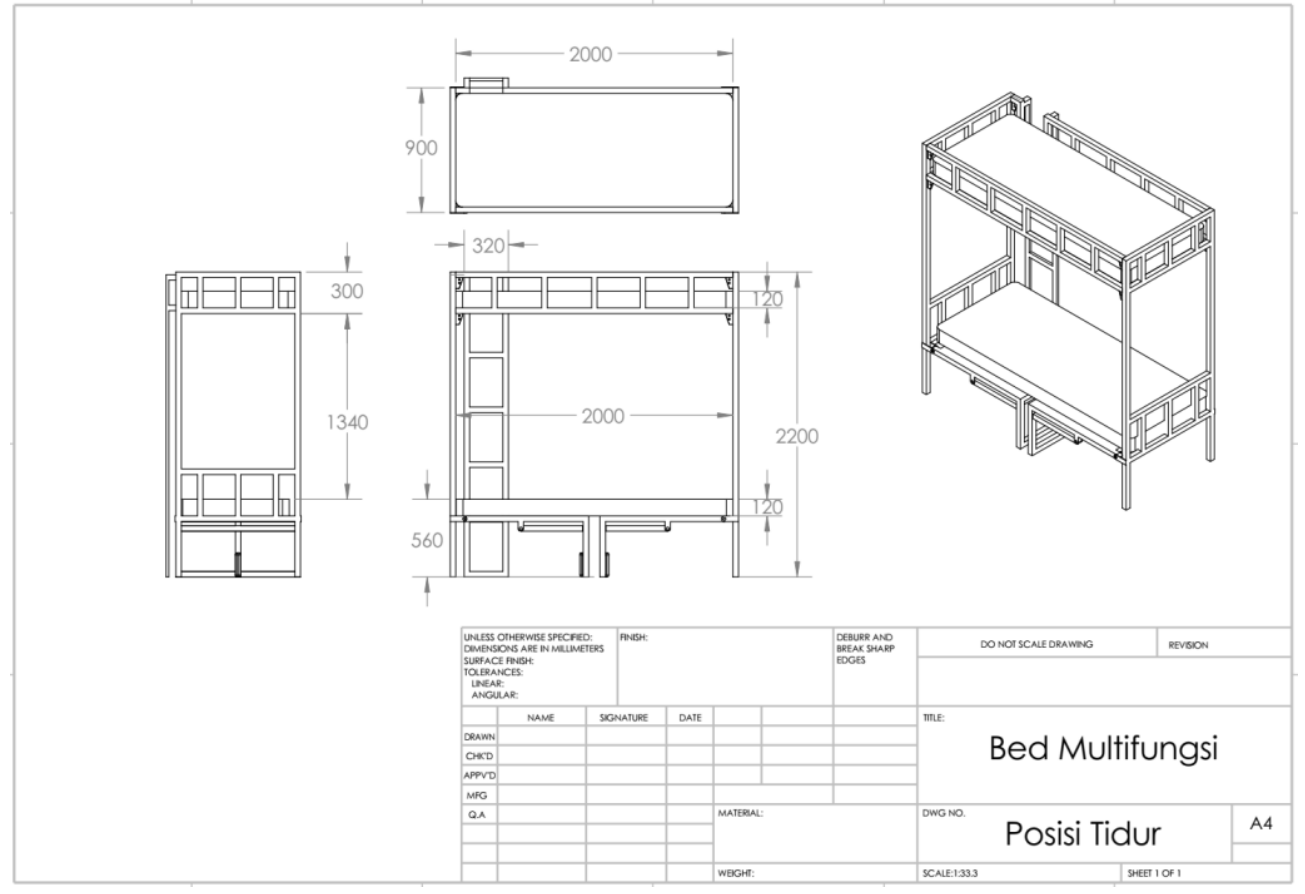

Gambar 6. Gambar teknik tempat tidur tingkat-meja belajar terintegrasi untuk tidur

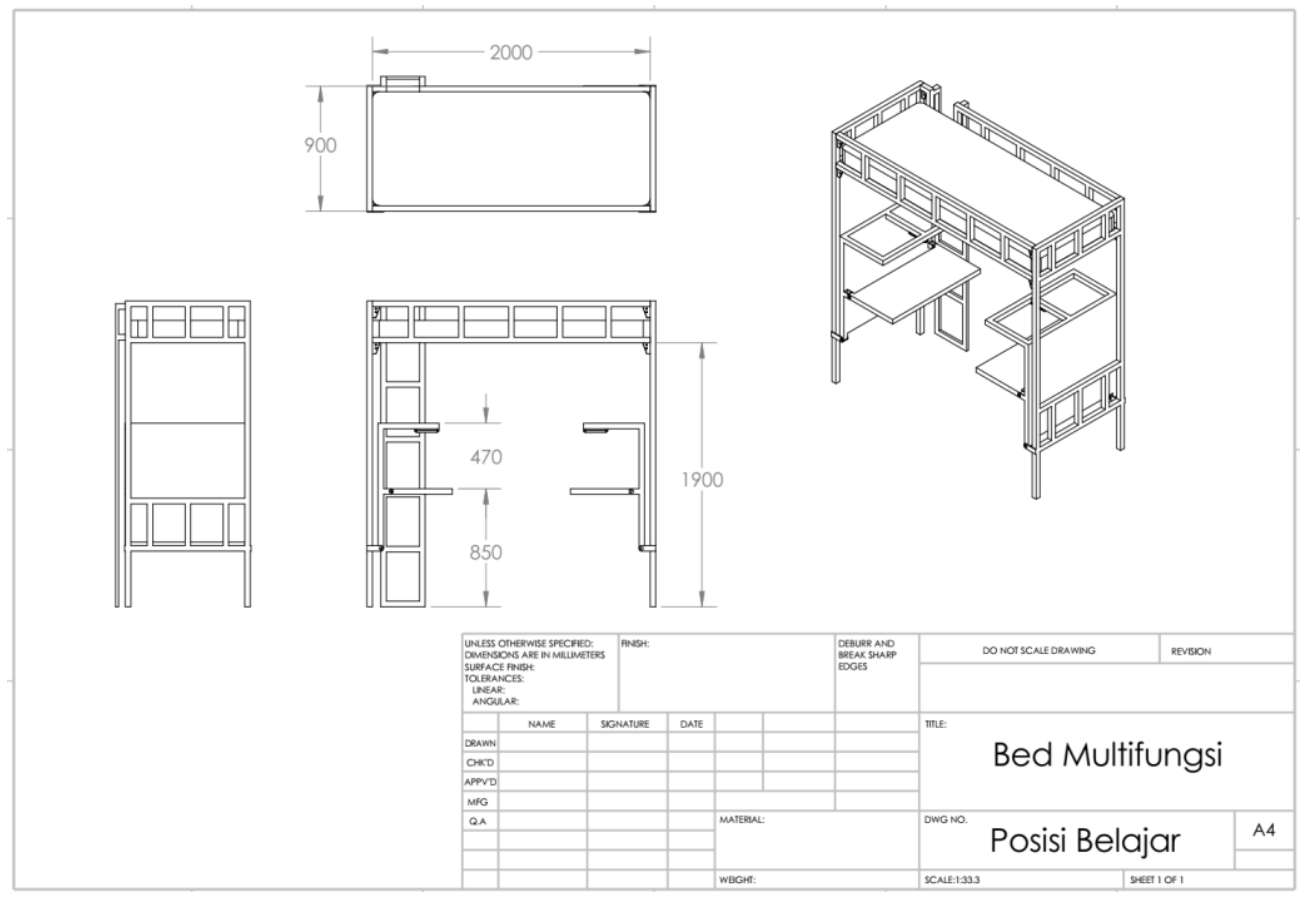

Gambar 7. Gambar teknik tempat tidur tingkat-meja belajar terintegrasi untuk belajar

\section{KESIMPULAN}

Kegiatan pengabdian kepada masyarakat untuk merancang dan membuat tempat tidur tingkat-meja belajar terintegrasi berhasil direncanakan dan dirancang pelaksanaannya. Mitra sasaran ada dua yaitu Pondok Pesantren Wirausaha Masjid Fatimah Ar Royyan dan Bengkel Las Sumber Rejeki. Pondok Pesantren Wirausaha Masjid Fatimah Ar Royyan adalah mitra pemakai yang bersedia memanfaatkan hasil ranacangan dan pembuatan tempat tidur tingkat-meja belajar terintegrasi. Bengkel las Sumber 
Rejeki adalah mitra pembuat yang bersedia mendukung pelaksanaan pengabdian ini dengan menyediakan fasilitas bengkelnya dalam pembuatan tempat tidur tingkat-meja belajar terintegrasi. Tim pengabdi UNS bertugas sebagai koordinator dan mendesain serta menggambar teknik agar proses pembuatan tempat tidur tingkat-meja belajar terintegrasi bisa berjalan dengan lancar dan sesuai dengan rancangan serta bisa dipakai dan dimanfaatkan sesuai dengan tujuan pengabdian.

\section{UCAPAN TERIMA KASIH}

Terimakasih diucapkan kepada Universitas Sebelas Maret Surakarta yang telah memberi dukungan dana pengabdian ini dengan Surat Kontrak Nomor: 261/UN27.22/HK.07.00/2021 Pelaksanaan Kegiatan Pengabdian sumber dana Non Anggaran Pendapatan dan Belanja Negara (APBN) UNS Tahun Anggaran 2021.

\section{DAFTAR PUSTAKA}

[1] Musabbikhah, Musabbikhah, and Samsul Bakhri. "Rekayasa Pembuatan Pakan Ternak Tambahan Berbahan Baku Limbah Pertanian Dan Perkebunan Untuk Mengurangi Konsentrat: Pemanfaatan dan Pengolahan Limbah Pertanian dan Perkebunan sebagai Pakan Ternak Mentok di KTTSR Boyolali." Abdi Masya 1.1 (2020): 21-26.

[2] Margono, Margono, et al. "Rancang Bangun Mesin Pencacah Rumput Untuk Peningkatan Efektivitas Konsumsi Pakan Ternak Di Sukoharjo." Abdi Masya 1.2 (2021): 72-76.

[3] Cahyono S. I., Triyono." Pelatihan Dasar Gambar Teknik Dengan Perangkat Lunak CAD Dalam Proses Perancangan" Abdi Masya 1.2 (2021): 83-91.

[4] K. Easterling, Introduction to the Physical Metallurgy of Welding, Butterworth Heinemann, 1992.

[5] S. Kou, Welding Metallurgy, Wiley Pub., 2003. 